Institutions and

Economic Performance 



\title{
Institutions and Economic Performance
}

\author{
Edited by \\ Elhanan Helpman
}

Harvard University Press

Cambridge, Massachusetts

London, England

2008 
Copyright $\odot 2008$ by the President and Fellows of Harvard College All rights reserved

Printed in the United States of America

\section{Library of Congress Cataloging-in-Publication Data}

Institutions and economic performance / edited by Elhanan Helpman.1 st ed.

p. $\mathrm{cm}$.

Includes bibliographical references and index.

ISBN-13: 978-0-674-03077-0 (cloth : alk. paper) 1. Economic development. 2. Regional economic disparities. 3. Public administration. 4. Social institutions. 5. Political culture.

6. Social structure. I. Helpman, Elhanan.

HD82.I347 2008

$338.9-\mathrm{dc} 22$

2008003052 